\title{
ЗАРУБІЖНИЙ ДОСВІД ЗАПОБІГАННЯ РОЗБІЙНИМ НАПАДАМ НА ЖИТЛО ГРОМАДЯН
}

\author{
Свір Павло Володимирович - здобувач Донецького юридичного інституту \\ МВС України
}

DOI:10.32782/EP.2020.1.30

УДК 343.915

У статті на основі вивчення зарубіжного досвіду (краӥн Европи, США, Японія) з'ясовано, що у сфері безпеки житла громадян провідну роль відіграють технічні системи захисту, зокрема автономна система захисту, керована кількома операторами, яка сама оиінюе ступінь загрози й може підняти тривогу, а також відбувається поступовий перехід від бізичної охорони (озброєної служби безпеки) до використання спещіальних засобів захисту й сигналізащій, які або самі нейтралізують загрозу, або сповіщають про неї полічію й службу безпеки. Виокремлено основні охоронні послуги та дії, що сприятимуть змічненню безпеки житла громадян в Україні. Запропоновано мінімальні стандарти безпеки житла громадян.

Ключові слова: розбій, власність, житло, зарубіжний досвід, запобігання.

Аналіз міжнародного досвіду боротьби зі злочинністю свідчить, що за сучасних умов злочинні прояви створюють реальну загрозу демократичному розвитку та національній безпеці більшості країн світу. Кримінальні елементи, маючи тісні міжрегіональні та міжнародні зв'язки, все частіше спрямовують свої зусилля на встановлення контролю над найбільш прибутковими сферами економічних відносин.

Відсутність єдиної національної концепції запобігання злочинам, неузгодженість загальнодержавних, регіональних, галузевих державних цільових програм соціальної профілактики за відповідними напрямками не сприяє запобіганню злочинності в країні. Таке становище не відповідає проголошеним конституційним положенням про соціальну, демократичну та правову державу, оскільки ситуація, що склалася, не враховує реалій сучасності, адже боротьба зі злочинністю давно перетворилася на глобальну світову проблему, яка набула не лише національного, а й міжнародного, транснаціонального характеру [1, с. 7].

Актуальність дослідження в цій сфері обумовлена тим, що протягом останнього десятиріччя в усьому світі спостерігається тенденція до зростання рівня злочинності, та, одночасно, брак заходів соціально-правового контролю від зростаючої криміналізації суспільних відносин.

В Україні відсутня схвалена на державному рівні концепція боротьби зі злочинністю, що обумовлено багатьма економічними, соціальними, політичними, правовими й іншими особливостями та протиріччями розвитку ринкових відносин в країні: не завершено створення системи кримінальної юстиції; триває реформування правоохоронних органів; продовжується розбудова національного законодавства; впроваджуються державні інституції, які повинні відповідати кращим європейським і світовим стандартам у цій сфері суспільних відносин.

В нашій державі, як і в інших країнах близького зарубіжжя, зруйновано створену за радянських часів систему профілактики, яка, не зважаючи на певні вади, була порівняно дієвою, демонструючи приклади 
взаємодії між правоохоронними органами i населенням.

Запобіганню розбійним нападам на житло громадян в Україні, певною мірою має сприяти вивчення превентивної діяльності правоохоронних структур іноземних країн світу і запозичення їх позитивного досвіду.

Інтеграція України до Европейського Союзу в умовах сучасного політичного і соціально-економічного стану зумовлює реформування усіх галузей українського законодавства відповідно до європейських стандартів, у тому числі і кримінальної. Особливо важливими питаннями є охорона життя людини і встановлення за посягання на нього адекватної міри відповідальності. Людина, їі життя і здоров'я є сферою, охорона якої регламентується, як міжнародноправовими нормами, так і національними. Так, ст. 6 Міжнародного пакту про громадянські і політичні права звертає увагу на невід'ємність права кожної людини на життя, охорону даного права законом і неможливість протиправного позбавлення життя [2]. У свою чергу, на національному рівні, захист даних соціальних цінностей передбачається нормами, які містяться в розділі II «Злочини проти життя та здоров’ я особи» Кримінального кодексу України [3].

Враховуючи важливість даної охоронюваної сфери, необхідним є вивчення досвіду зарубіжних країн щодо встановлення кримінальної відповідальності за злочини проти життя людини. Тому, особливої актуальності набувають компаративістські дослідження в галузі кримінального права, в тому числі і в частині кримінально-правової охорони життя людини від злочинних посягань.

Положення кримінального законодавства будь-якої держави світу, в тому числі й України, надають вирішального значення захисту прав, свобод та інтересів особи (людини). У ст. 3 Основного Закону нашої держави [4] проголошується, о людина, іiі життя та здоров’я, честь і гідність, недоторканність i безпека визнаються в Україні найвищою соціальною цінністю. Звідси кримінальноправова протидія злочинам проти особи є одним 3 найнагальніших і найпріоритетніших завдань нашої держави. Не випадково, що такі вимоги закріплені й у КК України
[3]. Зокрема, ст. 1 цього Кодексу встановлює, що він має своїм завданням «правове забезпечення охорони прав і свобод людини», а група злочинів проти особи обіймає першу п’ятірку нормативних пріоритетів у системі Особливої частини КК України.

Поняття розбійних нападів на житло громадян є кримінологічним і до певної міри умовним. Ним охоплюється злочин передбачений статтею 187 КК України. Поряд з тим цей злочин за низкою загальних ознак утворюе єдину кримінологічну групу, що виступає як єдиний об'єкт кримінологічного дослідження.

Правомірність виділення в окрему підсистему насильницьких злочинів заперечень не викликає та грунтується на подібності об'єктивної сторони цих злочинів, що полягає у застосуванні різних форм насильства, а також подібності детермінант цих злочинів та характеристик злочинців, які вчиняють злочини цієї категорії.

Однак визначення категорії «насильницькі злочини» лише на підставі об'єктивних критеріїв призводить до надто широкого тлумачення цього поняття. Прикладом такого підходу є законодавче визначення насильницького злочину, що міститься у Зводі законів Сполучених Штатів (§ 16 глави 1 «Загальні положення»):

«(а) посягання, елементом якого є застосування, спроба застосування або погроза застосування фізичної сили стосовно особи або майна іншої особи, або

(b) будь-яке інше посягання, що є фелонією, яке за своїм характером становить значну небезпеку того, що в процесі здійснення посягання на особу або майно іншої особи може бути застосована сила» [5, с. 71; 6, с. 201].

В окрему категорію виділено злочинні діяння, пов'язані з насильством, у кримінальному законодавстві Іспанії [7]. Крім того, КК Іспанії визначає особливості відтермінування виконання покарання і заміни покарання більш м'яким у разі засудження за злочинні діяння цієї категорії, а санкції статей Особливої частини, які передбачають відповідальність за насильницькі злочини, містять вказівку на обов'язкове позбавлення засудженого права носіння і зберігання зброї. 
Таким чином, розгляд поняття насильницьких злочинів лише за об'єктивним критерієм незалежно від того, чи є ці дії конструктивним елементом складу злочину, чи ні, та неврахування при цьому суб'єктивного критерію, яким виступає наявність специфічного мотиву (особиста неповага, помста, ревнощі, задоволення статевої пристрасті, хуліганські спонукання), і мети (заподіяння смерті, тілесних ушкоджень або психічної шкоди), вчинення злочину всупереч волі потерпілого, призводить до розширеного розуміння цієї категорії злочинів та поглинання нею корисливо-насильницьких 3лочинів.

Саме тому, на нашу думку, більш правильним є поділ усіх видів насильницьких злочинівнавласненасильницькійнасильницькі злочини з корисливою метою. У свою чергу, до власне насильницьких злочинів пропонуємо відносити умисні вбивства, заподіяння шкоди своєму здоров'ю різного ступеня тяжкості, хуліганство, поєднане $з$ насильством, згвалтування, а до насильницьких злочинів 3 корисливою метою - розбійні напади, грабежі, поєднані з насильством.

Наприклад, на формування злочинів проти власності в СІІА значний вплив справило англійське загальне право. Проте, в американському кримінальному законодавстві було вироблено чимало власних положень щодо «майнових» посягань (наприклад, криміналізовано окремі види крадіжок, грабежів та шахрайств; відмежовано вимагання від рекетирської діяльності; здійснено нове тлумачення деяких понять і термінів тощо). У ФККП США злочини проти власності передбачені різними главами розд. 18 Зведення законів (приміром, підпал - гл. 5; привласнення (розтрата) та крадіжка - гл. 31; вимагання - гл. 41; шахрайство й удавані заяви - гл. 47; злонавмисне пошкодження майна - гл. 65; рекет - гл. 95; пограбування й берглері - гл. 103; викрадене майно - гл. 113; телемаркетингове шахрайство - гл. 113А тощо) [8, с. 480-866]. Зрозуміло, що таке специфічне розташування нормативного матеріалу створює певні труднощі щодо його розуміння для українських юристів, через це, для більшої зручності, ми побудуємо аналіз федеральних кримінально- правових норм відповідно до послідовності розташування відповідних статей у розд. VI Особливої частини КК України [6, с. 332].

Специфікою федерального кримінального законодавства США є те, що, на відміну від КК України, воно чітко не розмежовує між собою поняття «грабіж» (передусім насильницький) і «розбій». Натомість ці два злочини пов'язані між собою єдиним поняттям «робері» (robbery), яке у вітчизняній юридичній літературі перекладається як «пограбування». Взагалі пограбування можна визначити як вилучення чи замах на вилучення чогось цінного, що належить іншій особі або перебуває під іiі охороною, або у володінні іншої особи чи осіб, шляхом застосування насильства та/або залякування жертви [9]. Пограбування є передусім насильницьким (за способом) злочином, що підтверджує класифікація ФБР, а отже, одним 3 найнебезпечніших посягань на власність. Такий підхід загалом відповідає й позиціям українських науковців. Ззокрема, M. I. Панов доводить, що спосіб насильницького грабежу та розбійного нападу буде більш суспільно небезпечним, ніж спосіб крадіжки та шахрайства [10, с. 138].

У зв'язку з тим, що запобігання злочинам у розвинутих країнах світу надається важливе значення, виникає необхідність впровадження їх позитивного досвіду i в Україні. Так, для США характерно позитивні напрацювання боротьби зі злочинністю в загальнонаціональному плануванні, а для Японії - на місцевому рівні. Зокрема, у 1970 p. Конгрес США прийняв Закон про контроль за організованою злочинністю, який передбачає низку законодавчих і профілактичних заходів щодо запобігання злочинам, що підлягають федеральній юрисдикції. У США також розширюється залучення громадян у профілактичну роботу, де існуе інститут добровільних помічників поліції.

Низька криміналізація японського суспільства пояснюється активною підтримкою поліції у запобіганні злочинам, високою дисципліною суспільства. Система профілактики в Японії зорієнтована на місцеві програми запобігання злочинам, містить як заходи кримінологічного вивчення стану злочинності, так і конкретні заходи за- 
побігання злочинам. Функції ранньої профілактики здійснюють спеціальні органи реабілітаційної допомоги, в яких працюють добровільні та штатні співробітники. Активно використовуються муніципальні програми, в яких бере участь населення районів. В Японії також діє асоціація профілактики злочинів - громадсько-державна організація, що функціонує на різних рівнях при кожному відділенні поліції, а іiї нижчими ланками $є$ пункти запобігання злочинам, які працюють у контакті з квартальними комітетами самоврядування. Запобіганням злочинам неповнолітніх займається асоціація та іiі структурні підрозділи у всіх префектуpax [11, c. 95].

У Франції у 1983 р. створено Національну раду із запобігання злочинам, до якої увійшли члени парламенту, мери міст, міністри, експерти, представники бізнесових структур. Головою Національної ради із запобігання злочинам є прем'єр-міністр країни. Рада вирішує такі завдання: фінансує програми запобігання злочинам; інформує громадськість про стан справ зі злочинністю; розробляє національну політику у сфері боротьби зі злочинністю, стимулює державні антикримінальні ініціативи, координує взаємодію між місцевими органами влади, громадськими організаціями і приватним сектором [12, с. 122].

У Великій Британії з 1966 р. працює Постійна конференція 3 профілактики злочинів, до якої входять представники Конфедерації британських промисловців, Торговельної палати, профспілок і Асоціації старших офіцерів поліції. У складі цієї організації діють робочі групи, які спеціалізуються на запобіганні грабежам та розбійним нападам [12, с. 88].

Значним досягненням системи профілактики злочинів розвинутих іноземних країн слід визнати ії грунтовне правове забезпечення. Урядові програми містять визначення напрямів соціологічних досліджень, розробку їхніх методик, підготовку персоналу, фінансування, організацію і реалізацію превентивних заходів з акцентом на ранню профілактику [13, с. 132].

Програми часто передбачають систему заходів спеціально- кримінологічної пре- венції, які належать до сфери кримінального, процесуального і пенітенціарного права. Характерною рисою у боротьбі зі злочинністю у СШАА в останні десятиліття 6 прагнення до централізованого планування і координації даної сфери діяльності, створення для цього спеціальних органів і наділення їх досить широкими повноваженнями.

У багатьох країнах світу створено аналогічні органи, які систематично аналізують стан справ у сфері запобігання злочинності й дають належні рекомендації урядовим структурам для прийняття відповідних рішень. Наприклад, в Австрії існує консультативна служба із запобігання злочинності, що має 143 регіональних бюро; у Бельгії Вища профілактична рада; у Данії - Вища рада профілактики, до якої входить 46 організацій; у США в рамках Національної ради створено профілактичні служби, що поєднують понад 100 громадських і державних організацій [14, с. 133].

Слід погодитись із пропозицією про створення в Україні спеціального державного органу, основними завданнями якого повинні бути: визначення основних напрямків державної політики у сфері протидії злочинності; проведення загальнонаціональних досліджень щодо рівня латентної злочинності; аналіз проявів корисливої та насильницької злочинності; координація діяльності державних структур та правоохоронних органів $з$ питань реалізації заходів запобігання злочинам; узагальнення практики запобігання злочинам; організація міжнародного співробітництва щодо запобігання злочинам тощо.

3 огляду на прорахунки минулих років цей орган доцільно наділити відповідним організаційно-владним статусом і правом видавати обов'язкові для виконання рішення, розпоряджатися матеріально-технічними й фінансовими ресурсами з метою забезпечення єдності кримінологічної політики у масштабах держави.

Проте за відсутності подібних державних структур запобіганню злочинності в Україні певною мірою має сприяти вивчення превентивної діяльності правоохоронних структур інших країн світу і запозичення їх позитивного досвіду. Можна з упевненістю 
сказати, що це є нагальною потребою для України, яка прагне стати повноправним членом Европейського Союзу.

Варто також погодитись 3 висновком В. В. Аунєєва, що злочинність важко було приборкати в умовах правового свавілля в усіх сферах у рамках ліберальних установок [15, с. 321]. Крім того, невідкладні заходи повинні розроблятися не виконавчою, а законодавчою владою і забезпечуватися необхідними гарантіями суворого дотримання конституційних прав, а також мати відповідне фінансування.

Як приклад законодавчих актів, що створюють підгрунтя правового забезпечення запобігання розбійним нападам на житло громадян, варто навести Закон США «Про контроль над насильницькою злочинністю і правозастосовними органами» 1994 р., що посилюе боротьбу 3 насильницькими 3лочинами, а також забороняє продаж і зберігання 19 видів зброї. Репресивна спрямованість американського закону багатопланова. 3-поміж подібних заходів - і така несумісна 3 сучасними демократичними тенденціями міра, як поширення призначення смертної кари на понад 50 складів федеральних злочинів, особливо якщо вони вчинені фанатиками-терористами, патологічно агресивними людьми і розбійниками, ситуативними корисливо-агресивними, професійними та організованими злочинцями. Привертає увагу виділення поряд з програмами на потреби правозастосовних органів - 13,5 млрд дол. та пенітенціарну систему - 9,8 млрд, значних фінансових ресурсів на програми превенції - 6,9 млрд дол. Закон про контроль над насильницькою злочинністю та інші заходи, вжиті адміністрацією Д. Трампа, дали реальні позитивні результати. Насильницька злочинність у 2016-2019pр. за абсолютними показниками зменшилася на 25,7\% (коефіцієнт - на 29,7\%), умисні вбивства - на 36,7\% (коефіцієнт - на 40\%), згвалтування - на 16,0\% (коефіцієнт - на 20,4\%), напади - на 19,3\% (коефіцієнт - на 23,7\%) [16, p. 278-279].

Одним із заходів віктимологічної профілактики розбійних нападів на житло громадян є кримінально-правова реституція, тобто компенсація шкоди, що була за- вдана злочином. Такий досвід існує у Великій Британії, США, Канаді, Австралії та Новій Зеландії [17, с. 312]. В Японії ще у 1973 р. було організоване Товариство, відповідальне за інститут компенсації потерпілим.

Зазначеним питанням приділялась увага і в Свропейській конвенції по відшкодуванню шкоди жертвам насильницьких злочинів від 24 листопада 1983 р. [18], грунтуючись на положеннях якої, з метою вдосконалення правового й організаційного механізму захисту законних прав та інтересів осіб, які потерпіли від злочинів, а також упровадження міжнародних принципів захисту законних прав та інтересів потерпілих Указом Президента України була схвалена Концепція забезпечення захисту законних прав та інтересів осіб, які потерпіли від злочинів, від 28 грудня 2004 р. № 1560/2004 [19].

Дослідження кримінологічної безпеки житла громадян надає підстави для висновку, що при постійному технічному прогресі збільшується технічна оснащеність не тільки житла, а й злочинців, а тому досягти абсолютного захисту неможливо. Отже, витрати на забезпечення безпеки повинні бути співрозмірними охоронюваним цінностям. Реальна безпека має передбачати не лише фізичну охорону житла, а й застосування технічних засобів захисту, спостереження й оповіщення. Однак, завжди слід враховувати, що будь-які технічні засоби використовуються людьми, які найчастіше відповідають за роботу систем охорони. Отже, без комплексного підходу не можна досягти вирішення проблем безпеки [20].

Програма соціального захисту має більш широку законодавчу основу (законодавство і суспільні договори) і акцентує увагу в основному на гарантуванні певного доходу в певний період часу. Іноді цей захист організується по лінії компанії. Соціальну допомогу здебільшого отримує лише постраждала особа. Законодавство ряду країн за недотримання цих соціальних гарантій неминуче тягне покарання від попереджень до штрафів, втрати ліцензії і навіть тюремного ув'язнення.

Наприклад, успіхи Японії у запобіганні розбійним нападам на житло громадян не можна пояснити якоюсь однією причиною. 
Низький рівень злочинності в даній країні пов'язується із низкою обставин соціальноекономічного, соціально-психологічного, правового, організаційно-управлінського, технологічного та іншого характеру. Щоб довести це, проведемо кримінологічний аналіз сучасної японської моделі запобігання злочинам, яка включає наступні напрями (стратегії) запобіжної діяльності: 1) багатолітня реалізація стратегії «соmmunity policing» (політика орієнтування на місцеві громади); 2) заходи в межах загальносоціального запобігання злочинності; 3) ефективна кримінальна політика; 4) впровадження досягнень науки і техніки в діяльність із протидії злочинності [21, с. 22].

Багатолітня реалізація стратегії «community policing» (політика орієнтування на місцеві громади). Вказаний напрям запобіжної діяльності названий першим свідомо, оскільки, на наше переконання, в Японії використанню громадського ресурсу, на відміну від інших країн світу, приділяється значна увага протягом кількох десятиліть. Японськими дослідниками зазначається, що базисом національної моделі запобігання злочинності можна вважати тісні зв'язки місцевого населення і поліції. Для цього ще у 30-х роках XX ст. в Японії створюються асоціації запобігання злочинності, які функціонують до цього часу. Показовим $\epsilon$ те, що з 60-х років XX ст. їх діяльність набула загальнодержавного характеру. Вони організовуються при поліцейських відділках і фактично представляють собою посередницьку ланку у взаємодії японської поліції 3 населенням. До основних форм роботи асоціацій можна віднести: а) інформування поліції про злочини, правопорушення та інші події, які трапилися на території обслуговування конкретного поліцейського відділку; б) просвітницька діяльність серед громадян про рівень криміногенності у конкретній префектурі (адміністративно-територіальні одиниці Японії); в) поширення серед місцевого населення інформації, спрямованої на зменшення його віктимізації; г) здійснення кримінологічної поінформованості громадян за місцем їх роботи.

Підсумовуючи викладене, зауважимо, що вивчення правоохоронної практики бо- ротьби зі злочинністю у розвинутих країнах світу та запозичення їх позитивного досвіду, досить важливо для України, яка прагне стати повноправним членом світового співтовариства.

\section{Список використаних джерел:}

1. Вербенський М. Г. Транснаціональна злочинність: монографія. Дніпропетровськ: Дніпроп. держ. ун-т внутр. справ; ᄉіра ЛТД, 2009. 356 с.

2. Міжнародний пакт про громадянські і політичні права від 16 грудня 1966 року Верховна Рада Украйни. URL: http:// zakon4.rada.gov.ua/laws/show/995_043.

Назва з екрана.

3. Кримінальний кодекс України від 05 квіт. 2001 р. № 2341-III. Верховна Рада Украӥни. URL: http://zakon5.rada.gov.ua/laws/ show/2341-14.

4. Конституція України: Закон від 28 черв. 1996 р. № 254к/96-ВР. Верховна Рада Украйни. URL: http://zakon2.rada.gov.ua/laws/ show/254\%D0\%BA/96-\%D0\%B2\%D1\%80.

5. Уголовное законодательство зарубежных стран (Англии, США, Франции, Германии, Японии) : сб. законодательных материалов / под. ред. И. Д. Козочкина. Москва, 1998. 270 с.

6. Савченко А. В. Порівняльний аналіз кримінального законодавства України та федерального кримінального законодавства Сполучених Штатів Америки: дис...докт. юрид. наук: 12.00.08. Київ, 2007. 616 с.

7. Кримінальний кодекс Іспанії (іспанською мовою) (del Código Penal). URL: http://www.igsap.map.es/cia/dispo/7734.htm.

8. Federal Criminal Code and Rules. St. Paul, Minn., West Group, 2003. 1436 p.

9. Definitions for crime trends from the FBI's Uniform Crime Reports. Criminal Offenses. URL: http://www.fbi.gov

10. Панов М. І. Вибрані наукові праці 3 проблем правознавства; передм. В. П. Тихого. Київ: Ін Юре, 2010. 812 с.

11. Боков А. В. Организация борьбы с преступностью в зарубежных странах: монография. Москва : ЮНИТИ-ДАНА, Закон и право, 2010. 175 с. 
12. Полиция зарубежных стран: система организации и опыт профессиональной подготовки кадров: учебн. пособ. / Асямов С. В., Миразов Д. М., Таджиев А. А., Якубов А. С. Ташкент: Издательство «Fan va texnologiya», 2010. 452 c.

13. Алексеев А. И., Герасимов С. И., Сухарев А. Я. Криминологическая профилактика: теория, опыт, проблемы: монография. Москва : Норма, 2011. 310 с.

14. Клочко А. М. Досвід зарубіжних країн у сфері боротьби зі злочинністю. Європейсъкі перспективи. 2012. № 3. Ч.2. С. 132-135.

15. Аунеев В. В. Курс мировой и российской криминологии : в 2 т. Т. II : Особенная часть: учебник. Москва : Юрайт, 2013. 872 c.

16. Sourcebook of Criminal Justice Statistics. Wash., 2020. P. 278-279.

17. Джужа А. О Реституція та компенсація як особливі форми віктимологічного запобігання злочинам: досвід країн Західної Европи та СIIA. Науковий вісник Національної академії внутрішніх справ. 2017. № 1 (102). С. 312-322.

18. Європейська конвенція щодо відшкодування збитку жертвам насильницьких злочинів (ETS № 116): Конвенція Ради Европи від 24 лист. 1983 р. Верховна Рада Украӥни. URL: http://zakon3. rada.gov.ua/laws/show/994_319

19. Про Концепцію забезпечення захисту законних прав та інтересів осіб, які потерпіли від злочинів: Указ Президента України від 28 груд. 2004 р. № 1560/2004. Верховна Рада Украйни. URL: http://zakon3. rada.gov.ua/laws/show/1560/2004

20. Эффективность защиты жилья. Опыт Франции. Технологии защиты собственности. URL: http://www.opta.com.ua/artext.asp?id $=58 \& \mathrm{~mm}=2$ 14/04/2003.

21. Колодяжний М. Г. Кримінологічний аналіз японської моделі запобігання злочинності. Вісник кримінологічної асоціації України. 2015. № 3 (11). С. 20-33.
Зарубіжний досвід запобігання розбійним нападам на житло громадян

У статті на основі вивчення зарубіжного досвіду (країн Европи, США, Японія) з'ясовано, що у сфері безпеки житла громадян провідну роль відіграють технічні системи захисту, зокрема автономна система захисту, керована кількома операторами, яка сама оцінює ступінь загрози й може підняти тривогу, а також відбувається поступовий перехід від фізичної охорони (озброєної служби безпеки) до використання спеціальних засобів захисту й сигналізації, які або самі нейтралізують загрозу, або сповіщають про неї поліцію й службу безпеки. Виокремлено основні охоронні послуги та дії, що сприятимуть зміцненню безпеки житла громадян в Україні. Запропоновано мінімальні стандарти безпеки житла громадян.

У зв'язку з тим, що запобігання злочинам у розвинутих країнах світу надається важливе значення, виникає необхідність впровадження їх позитивного досвіду і в Україні. Так, для CIIIA характерно позитивні напрацювання боротьби зі злочинністю в загальнонаціональному плануванні, а для Японії - на місцевому рівні. Зокрема, у 1970 р. Конгрес США прийняв Закон про контроль за організованою злочинністю, який передбачає низку законодавчих і профілактичних заходів щодо запобігання злочинам, що підлягають федеральній юрисдикції. У США також розширюється залучення громадян у профілактичну роботу, де існує інститут добровільних помічників поліції.

Низька криміналізація японського суспільства пояснюється активною підтримкою поліції у запобіганні злочинам, високою дисципліною суспільства. Система профілактики в Японії зорієнтована на місцеві програми запобігання злочинам, містить як заходи кримінологічного вивчення стану злочинності, так і конкретні заходи запобігання злочинам. Функції ранньої профілактики здійснюють спеціальні органи реабілітаційної допомоги, в яких працюють добровільні та штатні співробітники. Активно використовуються муніципальні програми, в яких бере участь населення районів. В Японії також діє асоціація профілактики злочинів - громадсько-державна організація, що функціонує на різних рівнях при кожному відділенні поліції, а ії нижчими 


\section{Дискусії, обговорення, актуально}

ланками є пункти запобігання злочинам, які працюють у контакті з квартальними комітетами самоврядування. Запобіганням злочинам неповнолітніх займається асоціація та іiі структурні підрозділи у всіх префектурах. У Франції у 1983 р. створено Національну раду iз запобігання злочинам, до якої увійшли члени парламенту, мери міст, міністри, експерти, представники бізнесових структур. Головою Національної ради із запобігання злочинам 6 прем'єр-міністр країни. Рада вирішує такі завдання: фінансує програми запобігання злочинам; інформує громадськість про стан справ зі злочинністю; розробляе національну політику у сфері боротьби зі злочинністю, стимулює державні антикримінальні ініціативи, координує взаємодію між місцевими органами влади, громадськими організаціями і приватним сектором. У Великій Британії з 1966 р. працює Постійна конференція з профілактики злочинів, до якої входять представники Конфедерації британських промисловців, Торговельної палати, профспілок і Асоціації старших офіцерів поліції. У складі цієї організації діють робочі групи, які спеціалізуються на запобіганні грабежам та розбійним нападам.

Ключові слова: розбій, власність, житло, зарубіжний досвід, запобігання.

\section{Foreign experience in preventing robberies against housing}

In the article, based on the study of foreign experience (European countries, USA, Japan), it is found out that in the sphere of citizens' housing security the leading role is played by technical security systems, in particular an autonomous security system operated by several operators, which itself assesses the degree of threat and can raise alarm., and there is a gradual transition from physical security (armed security) to the use of special security and alarm systems that either neutralize the threat themselves or alert the police and security service. The basic security services and actions that will help to improve the safety of housing of citizens in Ukraine have been identified. The minimum standards of safety of housing of citizens are offered.

Due to the importance of crime prevention in the developed world, it is necessary to introduce their positive experience in Ukraine. Yes, the US is characterized by positive crime-fighting efforts in national planning, and Japan - at the local level. In particular, in 1970, the United States Congress passed the Organized Crime Control Act, which provides for a series of legislative and preventative measures to prevent crimes subject to federal jurisdiction. In the United States, there is a growing involvement of citizens in prevention work, where there is an institute of voluntary police assistants.

The low criminalization of Japanese society is explained by the active support of the police in crime prevention and the high discipline of society. The prevention system in Japan is focused on local crime prevention programs, contains both criminological crime screening measures and specific crime prevention measures. Early prevention functions are carried out by special rehabilitation assistance bodies, which include volunteer and full-time staff. Municipal programs are actively used in which the population of the districts is involved. In Japan, there is also the Crime Prevention Association, a non-governmental organization operating at different levels at each police station, and its lower links are crime prevention outlets that work in contact with quarterly selfgoverning committees. The Association and its structural units in all prefectures are engaged in the prevention of juvenile crime

In France, in 1983, a National Council for the Prevention of Crime was formed, comprising members of parliament, mayors, ministers, experts, and representatives of business structures. The Prime Minister is the head of the National Crime Prevention Council. The Council resolves the following tasks: it finances crime prevention programs; informs the public about the state of crime; develops national policies in the field of crime prevention, stimulates state anti-criminal initiatives, coordinates interaction between local authorities, public organizations and the private sector.

A Standing Conference on Crime Prevention has been operating in the UK since 1966, comprising representatives of the Confederation of British Industrialists, the Chamber of Commerce, trade unions and the Association of Senior Police Officers. The organization includes working groups that specialize in theft and robbery prevention.

Keywords: robbery, property, housing, foreign experience, prevention. 